\title{
DISCURSIVE AND PROCESSUAL SOCIALIZATION OF THE MASS INTO ACTS OF VIOLENCE: THE CASE OF RWANDAN GENOCIDE
}

\author{
Jeylan Wolyie Hussein \\ Haramaya University, Dire Dawa, Ethiopia.
}

The Rwandan genocide that led to the death of 800,000 Tutsi and 50,000 moderate Hutu is one of the most horrendous atrocities in human history. The genocide was the outcome of human's negatively orchestrated agency. It is of course 'ultra-genocidal' as it was extended to moderate Hutu who refused to cooperate with the ultra-nationalist ideology (Dutton, Boyanowsky \& Bond 2005; Campbell 2010). It was a planned, systemic and methodical massacring. It was the genocide in which ethnic extremists mobilized resources including the linguistic and cultural resources of the country to get the public incitement into mass slaughtering. The genocide was fundamentally rooted in the politics of hatred that spotlighted the better future of the Hutu in indiscriminately exterminating the Tutsi. The anti-Tutsi propaganda heightened Tutsiphobia and scapegoated them for the entire predicaments which the Hutu suffered throughout their history. When the genocide began, it seemed as if every Hutu, except some, was fulfilling their obligation to weed out the enemy.

The aim of this article is to recast the nature of the genocide and illustrate how destructive ideologies instigated people's social psychology and moral preparation for destructive fulfilment. Discourses of dehumanization (Hackett 2003) and other systems of ethnic devaluation were used to deepen xenophobia and ethnic hostility among the Hutu and the Tutsi. The genocidal activations were media-supported. The role of $R a$ dio Télévision Libre des Mille Collines (RTLM) was significantly high in particular. In addition to the radio, Kangura, a French-language newspaper, served as a powerful instrument to stoke ethnic hatred and prime appalling savagery and aggression against all Rwandans of Tutsi ethnicity (Stanton 2004; Winton 2008).

\section{Historical Background to Ethnic Dehumanization AND THE GENOCIDE}

The Hutu and the Tutsi lived together in the country for hundreds of years without any genocidal turn against one another. The Hutu are numerically the majority by far while the Tutsi are the minority. The former 
are agriculturalists whereas the latter are pastoralists. The Tutsi had also a sophisticated hereditary monarchic system. However, a significant difference in their social status and asymmetrical access to power and influence emerged with colonialism. The Belgian colonists applied a strict divide and rule system in the country to tear the groups asunder. This is the system in which one group is favoured and the other is disfavoured for colonial end.

Myths of the ethnic groups' diametrical differences were constructed and reconstructed to set off and solidify distinctions between them. The other colonial strategy of differentiation was identifying the functioning system, sophisticating or elevating its function so that it would fit the colonial goal. For instance, the Tutsi's monarchical history was taken as a reference to justify their continued domination in the political and socio-cultural offices of the colonial period. However, the major racialized myth of ethnic differentiation used to marginalize the Hutu and to accelerate the power and influence of the Tutsi was the well known Hamitic Hypothesis. The Hamitic Hypothesis is a racist hypothesis created to deprive the African people of the value of humanity and make them vulnerable to racialized dehumanization. It concludes that every footprint of material and spiritual civilization in Africa came with 'the Caucasoid', white race in black skin (Hamites) which are portrayed in the hypothesis as well civilized and quicker witted groups. The African people were depicted, on the other hand, as unsophisticated and passive recipients of civilization.

The hypothesis is a discourse of dehumanization created to justify the subjugation of groups on mere physical characteristics. Observable physical variations were used to essentialize the existence of deeper racial differences between the Hutu and the Tutsi. The Hutu were denigrated as sub-humans while the Tutsi (based on their Nilo-hamitic physiognomy) were praised as a racially superior group. The Belgian colonists monopolized important political offices for the Tutsi on the basis of the Hamitic hypothesis. They uplifted the Tutsi as good allies in the colonial rule and as a group whose active participation in the colonial system could not be forfeited (Reyntjens 1987). Thus, the colonial rule laid a strong cultural and psychological foundation for the politics of exclusion by preferring the Tutsi and relegating the Hutu, the allegedly racially inferior group, to a secondary position. The system dehumanized the Hutu by labelling them as people who are not capable of holding offices because of their racial defects.

One fundamental step towards discourse of ethnic dehumanization applied in Rwanda was the removal of the Hutu chiefs from their traditional power on the basis of mere sense of racial inferiority. However, the racially based ethnic categorization between the two was strongly 
sealed in 1933 when the colonists 'distributed ethnic identity cards to systematise the restriction of administrative jobs and higher education to Tutsis' (Kamola 2007, 578). In his eight stages of genocide, Stanton (2004) defines this type of racialized ethnic identification as symbolization of differences. It should be noted, however, that the process of symbolization itself was based on original racialized dehumanization and hyper-differentiation of the ethnic groups to dilacerate them for colonial end. Racialized ethnic categorization served as a weapon in the colonists' process of dehumanization. It was a discursive production and consolidation of racialized distinction to frame the divide-and-rule policy's underlying politics of exclusion and de-legitimization. The colonists intentionally issued identity cards that symbolize their colonial de-historicization, objectification, demonization and ultimate de-legitimization of the Hutu.

On the basis of racial explanations and to cement the racial differences between the Hutu and the Tutsi, the colonists also arranged a separate schooling system for Hutu and Tutsi sons. The aim was to give the Tutsi sons high standard education to equip them with the competence required to effectively function in colonial offices and in business activities. The Hamitic Hypothesis of ethnic superiority of Tutsi and inferiority of the Hutu was taught in schools and reiterated on other forums to perpetuate the racialized narratives. By depriving the Hutu access to better education and other capacity-building structures of modernization, the colonial system had set a solid normative barrier to hinder their process of becoming. The dehumanization project set a hard ground for ethnic vulnerability of the Hutu and superiority of the Tutsi. It also laid the psychosocial foundation for the Hutu's later vengeful and organized violence waged against the Tutsi (Woolf and Hulsizer 2005). As would be made clear later, out of deep ethnic animosity, the Hutu reinvented the discourse of originality and attacked the Tutsi by categorically depicting them as tricky foreign invaders who should be expunged out of a Rwanda that belongs, according to them, only to the Hutu.

The Hutu's extremist discourse is suggestive of the Nazi discourse about Jews in which Hitler and his compatriots wanted to ensure the health, purity, and growth of German by persecuting the Jews (Linke 2002; Afflitto 2000; Stanton 2004). By and large, there were two types of oppressive discourses in colonial Rwanda that solidified and maintained the myths of ethnic dissimilarity between the Hutu and the Tutsi. The first one was day-to-day verbal reiteration of the Hutu's inferiority and the Tutsi's superiority. The second form of discursive disadvantage was practical occupational, economic and political dominance which the Tutsi assumed and used to deepen the predicament of the Hutu. The two discursive mechanisms of social oppression reinforced each other and 
deepened injustices in the country. As time passed, dominance of the Tutsi and subordination of Hutu became the day to day reality. The discourses of ethnic inferiority and superiority caused an identity crisis that could lead to ethnic self-denigration and search for better category of self-identification.

The ethnic hostility between the two groups continued until 1959 when the Hutu revolted against the Tutsi. When the colonial rule ended in 1962, independent Rwanda was led by Hutu-dominated leaders. From 1962-1994, the Hutu-dominated government became explicitly prejudiced and brutal against the Tutsi. Thousands of people from the Tutsi ethnicity were massacred in this period. Instead of establishing a system ethnic equality and co-existence, the ruling system exercised open revenge by oppressing the oppressor. None of the perpetrators in the massacres were taken to court for trial and were instead valorised for their deeds. The political environment created a high climate of revenge and granted the perpetrators impunity for the crimes they had committed against humanity. In the early period of independence, hundreds and thousands of Tutsi fled the atrocities and took asylum in neighbouring countries such as Burundi, Uganda, the Democratic Republic of Congo, and Tanzania. Those in the country lived enduring discriminations waged against them by the heavy-handed government. Throughout 1980 's, the country suffered severe economic failures. Rural as well as urban poverty, youth unemployment, and fall in the values of agricultural products in the international markets were the major economic conundrums in the country that created general public discontent (Fujii, 2004). However, no matter how undemocratic and suppressive it was against the Tutsi, the Hutu government did not reach the stage of maximum brutality in which it mobilized the entire Hutu to participate in a genocide meant to erase the Tutsi from the planet.

News of invasion by the Rwandan Patriotic Front (RPF), however, worsened the government's attitude towards the Tutsi. RPF was a rebel force organized largely from the Tutsi refugees and exiles who were compelled to flee the country by the gruesome ethnic massacres imposed on them by the Hutu dominated government. The Hutu government expressed its wrath against the Tutsi's plan to recast their power and hegemony in the country. The Hutu-led government and RPF entered into an armed struggle that threw the country into a devastating civil war. The civil war was different from other civil wars in Africa in that it gradually evolved into an ideology of ethnic power in which resources and institutions were mobilized to eradicate the Tutsi through relentless genocide. The Hutu extremists used media to disseminate a propaganda of hatred and to prepare the people's social psychology for resolute revenge. Within few hours of the mysterious crashing of the plane that carried 
President Juvenal Habyarimana, the paramilitary blocked roads and pathways to start mass killings. The promptness of the genocidal action clearly indicated that the genocide was not a spontaneous eruption and the plane crash became just a pretext to enact a thoroughly planned and organized massacre. The extremists' social psychology for mass killing was moulded well so that from April 1994 onwards one would see ordinary Hutu side by side with the Interahamwe (the murder squads) slaughtering every Tutsi irrespective of age, sex, social class and religious category. It was the event in which the government mobilized resources and institutions and organized armed groups, unemployed youth and the ordinary people into a huge force of violence (Staub et al. 2005). To soften the massacring of the perceived enemy, the Hutu extremists used communal work as one of the imageries in their genocidal symbolism.

\section{The Genocidal Incitements Waged Against the Tutsi}

One outstanding circumstantial factor that pulled the Hutu into genocide was the extremists' systematic and methodical mobilization of institutions to win the hearts of the masses into the genocidal project. The extremists used language to dehumanize and demonize the Tutsi as a cancerous swelling that should be removed. They used language in the same way as the architects of genocide used language to incite public hatred against the Jews and Gypsies during the Second World War.

Dehumanization in whatever form it appears is an intentional process of imposing degrading attributes on individuals as well as the groups to which they belong to justify the remorseless destruction of the group (Hagan and Rymond-Richmond 2008). In Rwanda, the extremists intentionally created a hateful climate through extreme propagation of hatred and by instigating the Hutu to actively participate in brutal and destructive acts of genocide, rape, and other inhuman acts. The way the ordinary people participated in the brutalization of their fellow citizens suggest that difficult ethno-political circumstances drive innocent people to develop destructive motives. Post-genocidal researchers who interviewed the perpetrators indicated the perpetrators' view that they were moved into the atrocities by the overwhelming propaganda of hatred and suspicion that ripped them of their moral and emotional restraints. However, situational pressures may not necessarily create a brand new trait for destructive and brutal acts and shape a collective moral disengagement or moral vacuum required to act brutally. One can say that situational pressure can reinforce or boost up latent feelings of hostility. One good speculation is that the history of hostility was already underway in the country and had been feeding into intergenerational animosity. The history of the country in general and the post-1959 revolution in particu- 
lar reveals that one of the conditions for mass involvement in the genocidal acts was a sharp decline in humanistic values and the concurrent tolerance for impunity in the political scheme of the country. Throughout 1960s, 1970s, and 1980s, the Tutsi suffered several hate-driven atrocities. The RPF's insurgency in 1990 exacerbated the government's prejudice against the Tutsi and gave the extremists the ground for genocide.

Plagued by poverty and being aware that overall socio-economic conundrums had already caused huge frustration in the country, the government looked for something that would help it redirect the masses out of frustration and into vengeance. The government told the Hutu that they had throughout history been victims of the Tutsi's systematic and brutal oppression and that they would heal their wounds of oppression only through waging genocide against the enemy who, according to the propaganda, was still working against them. In one of the Hutu Ten Commandments published in Kangura No. 6 in December 1990, the Hutu men were told that Tutsi women were enemies clandestinely working to facilitate conditions for Tutsi dominance, power, and hegemony. It vehemently opposed the idea of Hutu men having Tutsi women as wives, secretaries, or concubines since this was seen as compliance. The print media drew red lights between the two ethnic groups in order to polarize ethnic divisions and justify indiscriminate eviction of the targeted group. It warned the Hutu against business partnership with the Tutsi. In a way that tears asunder the social fabric of the society, the publication advised the Hutu to exclude the Tutsi and advised them to strengthen their solidarity and stand firmly against their enemy (Kabanda 2007).

\section{The Discursive and Metaphorical Dimension of ETHNiC ViolenCE IN RWANDA}

The mass involvement into the genocide is the outcome of a huge frustration among the Hutu extremists due to poverty, unemployment, and misery. The extremists manipulated the phenomenon and made their equally frustrated masses scapegoat the Tutsi for their predicament which turned into bitter animosity against them. As Schimmel (2011) eloquently puts, the Rwandan genocide was 'a meticulously planned and executed project of extermination of all Tutsis in Rwanda by the government, army, militias and Hutu civilians' (1126). No single theory can fully explain the causes and dynamics of the extreme atrocities the country had undergone. Therefore, one should look for multiple mutually reinforcing and complementing theories. This situation is explained partially by frustration-aggression-displacement theory. The theory has it that the frustrating external event (. e.g. the war waged by RPF) creates an instigation to impulsive aggression and self-defensive. The purpose in 
frustration-aggression displacement is to forge shared understanding that the scapegoat is responsible for unhappy encounters. According to Dutton et al (2004), the public 'desperation enhances the ability of leaders to generate compliance with genocidal commands" and in the case of Rwanda, conformity to those commands was framed in terms of communal labour obligations. The killing was euphemized as 'doing the work,' and weapons as 'tools"' (454). The Hutu extremists' pre-occupation with metaphors and other nuances of symbolism will be discussed later in the article.

It should be clear, though, that frustration leads to aggression only when they are manipulated through and mediated by ideology. In Rwanda, the extremists manipulated the frustration for their own political or genocidal ends. That is why it is said that 'the proximal cause of organized aggression in response to shared frustrations is ideological rather than the result of a direct frustration-aggression link' (Glick 2002, 137).

Another factor that instigated the mass to act violently was the government's systematic achievement in terrorizing the Hutu by exaggerating the Tutsi's insurgency as a massive threat that devastates not only hard-won gains of the 1959 revolution, but the very survival of the ethnic Hutu in Rwanda. The theory that explains how the perceived threat by one's historical enemy drives people into massive violence is psychocultural interpretation theory (Staub 2002). In its explanation about the causes for people's engagement in extreme acts of violence such as genocide, psychocultural interpretation theory shares a lot of points with symbolic political theory. This theory asserts that violence and other extraordinary cruelties are caused by 'group myths that justify hostility, fears of group extinction, and a symbolic politics of chauvinist mobilization. The hostile myths produce emotion-laden symbols that make mass hostility easy for chauvinist elites to provoke and make extremist policies popular' (Kaufman 2006, 47). Writing of the Rwandan case, Kaufman (2006) states that 'Rwanda's genocide must have been motivated by an exceptionally hostile, eliminationist Hutu mythology aimed against the Tutsi.' He argues that the 'extreme mass hostility against Tutsi, and chauvinist mobilization based on manipulating ethnic symbols-all resulting in predation-driven security dilemma' (70). How the Hutu extremists used symbols to mobilize the mass into violence will be explained later through analysis of the metaphorical instruments mobilized for semantic effect in the context of the conflict.

At the onset of the genocide, most of the Hutu Rwandese carried out the massacre as an aspect of maintaining obedience to the their ethnic identity by joining others who during the period claimed to have been protecting their ethnicity from its plotted demise. The theory that explains why and how this identity-based self-commitment to atrocity oc- 
curs is social identity theory. In Rwanda, ordinary Hutu joined the atrocious campaign perplexed by the phobia which the genocidal propaganda created. They engaged themselves in the crimes not only to protect their survival, but also to reassert their positive social identity. However, this theory does not explain why all Hutus were not threatened and driven by the propaganda that created a high climate of fear among the Hutu. One can conclude only that the Hutu were subjected differently to the factors that shaped inter-group thinking and collaboration towards violence. There are theories that explain the reasons why attitudinal differences between individuals occur in aberrant conditions where 'habitually lawful social relations degenerate into unrestrained violence' (Akhavan 2001, 11). For example, Waller's four-pronged model developed to explain causes of human's extraordinary evils suggests that the individuals' psych-moral domains and sub-culture and psycho-social domain within the broader culture and psycho-social domain to which individuals and groups belong may affect their reaction and position. He classifies these two major domains into four levels of contributing factors. The first prong in the model is the distal forces of human nature which shape individuals' responses to authority such as ethnocentrism, xenophobia, and an innate craving for power and dominance. This factor largely involves a far-reaching impact of primordial forces and the pressure exerted on them by situational forces. The second one is identities of the perpetrator as shaped by cultural belief systems, ideological indoctrination, propaganda, moral disconnection, and the development of a moral imperative towards the victimization of others.

The third prong that influences individuals' responses to authority is defining the victims as the 'other' with the aim to exclude and inflict harm. Exclusion of victims as others and their ideological/genocidal dehumanization through euphemistic labels like "bacilli," "parasites," "vermin," "demons" and a "plague" used by the Nazi exterminators to target the Jews during the Second World War shape the perpetrators' negative perceptions of the victims and cause them to develop a strong propensity to reduce their value. The fourth prong in the model is the power of the situation that influences individuals' thoughts, feelings and behaviours. Situations include the process of brutalization (including gradual desensitization or habituation to atrocities), the binding factors of the group (influences of group dynamics that hold one accountable to the group and its activities) and the power differentials between the perpetrators and the victims (Waller 2001, 17-20; Dutton et al 2004, 268). In general, the individuals' degree of exposure to and influence by the psychology, history, evolution, and culture of atrocity influences their inclination towards or revulsion from the violence. The article would show how in Rwanda the psychological processes of brutalization desensitized the 
youth recruited into the paramilitary and made them to carry out killings without repulsion.

The factors for mass involvement in genocide can also be evaluated through two other lenses or approaches: the intentionalist and functionalist approaches (Gellately and Kiernan 2003).

Scholars who belong to the intentionalist paradigm posit that political leaders and other top-echelon functionaries design the genocidal project and mobilize resources including human beings to accomplish their plans. Most of the modern genocides including the Holocaust were orchestrated from the top. The supporters of this paradigm think that dictators such as Hitler scapegoated the groups they wanted to exterminate and mobilized the masses to exterminate them. All state-sponsored mass terrorism, slaughter, and dislocation that occurred in the world fall into this paradigm. In the Rwandan case, the Hutu-dominated government intentionally created the climate for genocide and mobilized the material and the spiritual resources necessary to carry it out. Machetes and clubs were imported and distributed to peasants to get them to kill their enemies. The youth were organized into paramilitary groups to become instruments of violence (Staub 2002; Jones 2002). The media became the channel through which the leaders instructed their people to kill the enemy. The media communicated to the masses the extremists' inflammatory rhetoric based in primordial ethnic passions and hatred in order to incite the Hutu to butcher the Tutsi who became scapegoats or dangerous enemies. The extremists underlined that annihilating the Tutsi meant elevating the Hutu.

The functionalist paradigm explains that genocidal ideologies are translated into reality when the perpetrators obey authorities and respond to the genocidal guidelines by engaging themselves in destructive measures. The leaders may instigate the ordinary killers to kill the enemy, but may not have control on the day-to-day practices of killing and that the ordinary people may fulfil their obligation by doing the killings in their own way. However, the architects of the genocide and the perpetrators share cultural-societal tilt. They belong to the same culture and live in a similar existential dilemma. In Rwanda, the ordinary perpetrators shared with the leaders 'the inclination for the same potentially destructive modes of fulfilment' (Staub 2002, 21). In this pre-planned and wellresourced genocide, the ordinary people participated in the killing, raping and mutilating body. By so doing, they fulfilled the extremists' genocidal intents. The ordinary Hutu were whipped into the massacre out of sense of imminent destruction which the Tutsi allegedly threatening.

As Fujii clearly puts it, 'By exploiting the situation to its fullest, the geńocidaires were able to use fear as the mechanism for making genocide appear not only normal and legitimate but indeed imperative given 
the circumstances' $(2004,112)$. It was the genocide that manipulated the public attention and concern by creating a heightened climate of irrational fear by disseminating false propaganda and reports. The main intention was to draw the whole Hutu population into the ethnic extinction of the Tutsi. The eliminationist ideology made Tutsi's annihilation a choiceness choice. The extremists directly told the Hutu 'kill or you will be killed'. Such a terrorization lends a 'script that justified a belief system for engaging in violent behavior found in the defiance stage of the violentization process' (Winton and Unlu 2007, 50). It is clear, however, that there was interaction between the top leadership of the genocide and the genocidal atrocities on the ground. The virulent acts on the ground gave the extremists the practical hope that the masses were in support of their annihilationist agenda. Ordinary people also felt that their government was sponsoring and leading the genocide to rescue them from clandestinely arranged brutality at the hands of the Tutsi. Arguably, it is only when the needs and inclination of the masses have congruence with that of the leaders that a high risk for massive involvement in genocide is created (Straub 2002).

In general, the Rwandan genocide was based in the massive diffusion of desperation, hatred, fear based on polarized ethnic differences. The genocide revealed that in such situations ordinary people are easily manipulated and driven into destructive actions. Paul Lederach reasons out well the reason behind the masses rush into destructive violence and how it is connected to the leaders' systematic manipulation of the perpetrators psychology. According to Lederach, "where there is deep, longterm fear and direct experience of violence that sustain an image of enmity, people are extremely vulnerable and easily manipulated." The reason is that "the fears in subgroup identities are often created, reinforced, and used by leaders to solidify their position and the internal cohesion of the group behind them." Lederach convincingly argues that "deep polarization and sharp divisions are, in fact, functional for increasing cohesion, reducing ambiguity, and decreasing internal criticisms of leaders." As in Rwanda, "a clearly defined and immediately present enemy and the perception that the group's survival is at stake inspire uncritical support of the group's leadership" $(1997,15)$. In Rwanda, the extremists fanned the flame of ethnic hatred and activated memories of systematic discrimination and subjugation in the past. By so doing, they caused divisive ethnic myths, stereotypes, hatred, and fears which permeated the fabric of society. When the genocide commenced, the crisis mentality had already developed into collective aggression which resonated with ordinary people.

In the genocide, a group's irrational fear of the retaliation of another group, staunch hatred of the allegedly threatening group, and the individuals' desire to quench their deep-set and multi-dimensional-based dispo- 
sition towards cruelty combined to effect destruction. This can be explained through violentization theory.

\section{Analysis of Discursive Preoccupation in The Violentization Processes}

The violentization theory discussed above has revealed that the Hutu-dominated government directed the propaganda of hatred against the Tutsi from the top and mobilized strategic resources to demonize them. Among the resources mobilized by the anti-Tutsi campaigners were symbols. The language of hatred used in the government controlled media regenerated a reification of socio-cultural and moral orientations in which ethnic categorization and dehumanization were encouraged. One of the linguistic tools used to propagate genocide was metaphor. Metaphors were used as instruments in discourses of dehumanization to achieve a vast and violent mobilization of the masses in support of the extremists' atrocious agenda.

Let us see what metaphors are and why they are used in communication before we see their application to the discourses of dehumanization in a genocidal setting. Metaphors have been defined in different ways by different scholars. In this paper, Charteris-Black's $(2004,21)$ definition is used: that a metaphor is 'a linguistic representation that results from the shift in the use of a word or phrase from the context or domain in which it is expected to occur to another context or domain where it is not expected to occur, thereby causing semantic tension'. On their part, Lakoff and Johnson (1980) stressed that the metaphorical use of language involves grasping and experiencing one thing in terms of another thing and that the process involves creating perceptual connections between the well-known thing and the thing to be known. For instance, through metaphorical thinking we come to know an abstract concept or phenomenon in light of a familiar one. According to Lakkof and Johnson (1980), metaphors structure how we understand one conceptual domain of our experience in light of another by projecting our knowledge of the familiar domain onto the unknown or less known domain. In other words, metaphors are tools that enable us to understand and describe what is otherwise difficult to grasp and describe. Cognition of the nature of the familiar domain draws to our mind frame of the new concept or phenomenon. Again, through metaphor we develop a new understanding of the things we already know.

In this article, the key metaphors used in the genocide will be identified. Then their meanings will be analysed by placing them within the ethnopolitical tension and the dynamics of conflict prior to and during the genocide. The metaphors and their ideological intentions, particularly their function in the process of othering, will be analysed and supported 
by post-genocidal texts and by witnesses to the genocide. The role of the metaphors in imposing the ideological and totalitarian view of ethnicity and their role in structuring metanarratives of differences and embodying ideological discourses of hatred will also be assessed. Attempts will be made in particular to indicate the metaphors' role in structuring hegemonic myths of ethnicity and in drawing conditions for reification that legitimize and normalize horrific violence toward others. The interaction between the top-down rhetorical campaign of ethnic elimination, ideological apprehension, intolerance, and detestation and the accomplishment of the genocide on the ground will also be examined. Finally, the genocide will be assessed through the lens of violentization theory.

A critical analysis of the expressions selected by Hutu extremists against the RPF and its supporters reveals that during the genocide, inflammatory rhetoric was used to foment genocidal violence. The extremists used common words such as river, work, machete, trees, roots and bushes for negative metaphoric effects. Below are shown metaphors with their discursive meaning, ideological underpinnings, or the shared social frame of reference intended in using them as well as the genocidal texts and post-genocidal witnesses which reveal the impact of the metaphor-based dehumanization. The genocidal metaphors were of three types: word-based, action-based and cosmological metaphors. Wordbased metaphors were use of cockroach and other dehumanizing languages to indignify, denigrate and dehumanize the Tutsi. These are similar to untermensch (German for under-human or sub-human) which Hitler and his compatriots used to degrade the Jews and other victims of European racisms during the Second World War. Action-based metaphors were physical atrocities such as brutal sexual abuse. Cosmological metaphors are situations in which the physical surroundings, as structured and organized entity were given symbolic meanings based on the day to day observations of the features of the cosmos.

The cosmos' discursive values had deep cultural roots and drew their meaning from the society's thinking about the metaphysical and structural attributes of the physical surrounding.

\section{WORD-BASED METAPHORS}

1. Inyenzi (cockroaches): this was the principal word in the Hutu extremists' discourse of dehumanization that equated the Tutsi with the difficult and plaguing insects that raid at night under cover of darkness (Fujii 2004). The ideological goal or shared social frame of reference it was intended to convey was dehumanization of the Tutsi in the eyes of the Hutu and validation of the mass violence to crush them out of hate. The metaphor was used to make easy the Tutsi's elimination. One genocidal text 
revealed that 'the cruelty of the inyenzi can be cured only by their total extermination' (Chrétien et al. 1995 cited in De Forges $2007,48)$. On the whole, inyenzi represented the infestation metaphor, comfort-wrecking plague and a fatal havoc. However, this metaphor hides one true reality. Given their small number, the Tutsi should not have been caricatured as cockroaches whose infestation covers all places. However, if the word was used to represent the ubiquitousness of the minority group's power and influence, the metaphor could be closer to reality. Kangura set intertextuality between Tutsi as night time raiders and Tutsi as uncontrolled controllers of all opportunities. To awaken the Hutu from their state of unconsciousness and to show how beleaguered they were by the Tutis, Kangura exaggerated that the country had already been taken by the Tutsi. 'The Tutsi became those 'who took everything', 'who are everywhere', who control the business sector, who govern despite appearances, who constitute the majority in the school system, both in terms of teachers and students, in the church and within all spheres that symbolize progress' (Kabanda 2007, 63). The aim of such statements was to fan flames of bitterness and rage. In general, the Hutu government's hate media transferred cockroach's physical and biological behaviours onto the Tutsi insurgents. The extremists used the term to dehumanize and demonize the targeted group as nighttime invaders, infesters, and lifetime plagues (Fujii 2004; White 2009). The metaphor carried multiple interrelated meanings. One was its use to signify the negative, underhanded, and elusive movement of the group. The second was the triviality and crushability of the group as a troublemaking force. The other inherent meaning of the metaphor was that the Tutsi, like cockroaches, raid surreptitiously. Most importantly was the devaluative impact of the metaphorical meaning of cockroach as a discourse of dehumanization. The cruelty and barbaric nature of the genocidal acts revealed that the ultimately brutal killings of human beings became as simple as crushing a cockroach. It seems that the demonization process gradually made the perpetrators triumph over the psychological and normative inhibitions against the ferocious and wild rush into killing. The portrayal of Hutu women as spies who clandestinely work for the Tutsi and the depiction of RPF as cockroaches have an axis of intertextuality (synchronization) since both construct negative framing of the Tutsi and their movement as deceptive and destructive.

2. Eaters of our sweat and burden up on our back: these metaphors with closer meanings were used to depict the Tutsi as burdens 
that were unfairly loaded on the Hutu, the producers and feeders of parasites whose heavy dependence has now become insufferable (Taylor, 2002). The metaphors synchronize also with the other metaphors which embody the meaning that the Tutsi are cunning, bloodthirsty, untrustworthy, and natural power-mongers. These metaphors were actively used to oppose RPF's insurgency and to create public apprehension that the enemy came to roll back the gains of the revolution and to re-enslave the Hutu (Higiro 2007).

3. Hamatic invaders from the north: the phrase was used to portray the Tutsi as a group that is bent on devastating and subjugating the Hutu. The ideological goal behind use of this phrase was myth-making meant to pit the Hutu against the Tutsi and send their bodies back to Ethiopia through the rivers that flow into Lake Victoria. The hate radio in the country depicted the Tutsi as "nomads and invaders who came to Rwanda in search of pasture, but because of their cunning and malicious nature, they managed to stay and rule. The Hutu were terrified that if they allow the Tutsi-Hamites to come back, they would see be subjugated by them in Rwanda, and also give the enemy an unfettered sphere of influence in other parts of the Great Lakes Region' (RTLM, 2 December 1993, cited in Mironko 2007, 127). 'Hamites' was used to signify that the Tutsi had no natural kinship with the Hutu majority who are the true descendents of the Bantu. Hamatizing the Tutsi was also a myth-making agenda meant to evoke in the Hutu the sense that the Tutsi should not belong to the region just as a poisonous weed does not deserve to flourish in a soil meant only for millet to prosper. In its February 1992, the Kangura publication stated: 'The Tutsi ethnic group is descended from the large family which we call 'Nilotic' or 'Hamite'. It is a family known for their propensity for war to the point that those countries of which they are members find themselves in a state of perpetual conflict. See what has happened in Somalia. You understand therefore what to expect in Rwanda (see Eltringham 2004, 37). The whole process involved blatant ethnic de-legitimization and exclusion.

4. Umuganda (communal work): the word represented a social obligation that every member of the society is expected to accomplish and use during the genocide as euphemism for killing the Tutsi. The ideological intention in using the word was to require that every Hutu take part in the ritual work of purifying the land of the enemy. One of the anti-Tutsi journalists broadcasted to his people: 'Mobilize yourself. Work you the youth, everywhere in 
the country, come to work with your army. Come to work with your government to defend your country' (animateur Georges Ruggiu's message to his RTLM listeners in June 5 1994, cited in Li 2007, 96). According to Taylor (2002), genocide actually became an engaging work for the unemployed and desperate Hutu youth for whom the government paid money because they had taken active role in enacting its genocidal agenda.

5. Weeds and roots: the entire Tutsi were depicted as invading weeds that should be removed together with their roots. The extremists' intention in depicting the Tutsi as 'weeds' was exhorting the Hutu to weed them out in order to clean the garden. Some perpetrators gave the testimony of how the media dehumanized the Tutsi as poisonous weeds that should be uprooted: 'The radio told us to clear the bushes. There was no person who did not hear that! RTLM said to 'separate the grass from the millet' [i.e., weed out the Tutsi]. Bikindi told people 'to pull out the poison ivy together with its roots (see Mironko 2007, 133). Similarly, a leaflet distributed in Ruhengeri préfecture in early 1991 stated: 'Go do a special umuganda. Destroy all the bushes and the Inkotanyi who are hiding there. And don't forget that those who are destroying the weeds must also get rid of the roots [women and children]' (see in Eltringham 2004, 191).

6. Ibyitso (traitors): the word was used to portray the Tutsi as the invisible enemy who harbours murderous intentions against the Hutu. All of Tutsi were categorized as a dangerous enemy that deceptively stays in the society waiting only for the right time and condition to turn murderous. The ideological intention in utilizing the metaphor was exhorting the Hutu to act before they are acted upon. For example, an article in Kangura in December 1990 stated "The enemy is always there, among us, and only waiting for the right moment to try and liquidate us" (Chrétien 1991, cited in Eltringham 2004, 23). In his rhetoric of exclusion and extermination made in November 22, 1992, Leon Mugesera addressed his comrades with the following statements about the Tutsi who he portrayed as traitors. He clearly indicated in his statements that the Hutu should not hesitate in their action and that their action should be the fast and quick annihilation of their enemy. According to him, "they [the Tutsi in the country] have plotted to undermine our armed forces. ... The law is quite clear on this point: "Any person who is guilty of acts aiming at sapping the morale of the armed forces will be condemned to death.' What are we waiting for? ... And what about those accomplices (ibyitso) here who are sending their children to the RPF? Why 
are we waiting to get rid of these families? ... We have to take responsibility into our own hands and wipe out these hoodlums. . . The fatal mistake we made in 1959 was to let them [the Tutsis] get out. . .." (cited in Taylor, 2002, 159). The word ibyitso makes symbolic and ideological synchronization with other words of similar ideological tone such as cunning, malicious, and manipulators used to disparage all persons of Tutsi ethnicity.

\section{ACTION-BASED METAPHORS}

The Hutu perpetrators participated in the dehumanization and brutalization process through a physical cruelty that spoke louder than words.

1. Mutilating and disfiguring of reproductive organs: the atrocity involved among other things emasculating Tutsi men and slashing off the breast of Tutsi women to disrupt their social reproduction. Reproductive organs were mutilated to show not only hatred, but also dominance. It was a harsh measure that corroborated well with the generic goal of genocide. It was taken as a way of stopping the Tutsi's ontological continuity. Asked what he observed, Roméo Dallaire, the commander of the United Nations peacekeeping force during the Rwanda genocide, had to testify before the ICTR that 'young girls, young women, would be laid out with their dresses over their heads, the legs spread and bent. You could see what seemed to be semen drying or dried. And it all indicated to me that these women were raped. And then a variety of material were crushed or implanted into their vaginas; their breasts were cut off' (cited in Nowrojee 2007, 363). Disembowelling pregnant women (Straus 2004) also belongs to the same metaphor of brutality.

2. Obstructing the natural and normal flow of sexuality: one of the atrocities committed during the genocide was forcing persons to make sexual intercourse with their own children, the process that obliged blood and semen to flow in-ward and wrongly instead of flowing outward and rightly. In the country's sexuality taboo, doing sex with one's children is an aspect of misdirected and ontologically wrong and self-destructive performance of reproduction. According to Taylor (2002), the victims were forced into a calamitous process of causing their own 'blood and semen to flow backward upon one another in a closed circuit within the family rather than in an open circuit between families.' In addition to being brutalized and dehumanized, the bodies of the Tutsi 'were transformed into icons of asociality, for incest constitutes the preemption of any possible alliance or exchange relation that 
might have resulted from the union of one's son or daughter with the son or daughter of another family' (169). Inherently, this form of brutalization and dehumanization is an aspect of making the Tutsi become causes of their own destruction. The gratuitous brutality was harm-doing to the entire group and was deliberately imposed with clear knowledge and understanding of the physical and psycho-social destructions it causes to the victims. It shows also that genocide is more than killing a person or group of persons bodily, but it also involves atrocities committed to cause psycho-social devastation.

3. Brutalizing rape: this involved imposition of dehumanizing treatment in the form of forced insemination. The ideological goal of the action was encouraging the Hutu to dominate the Tutsi and break their hegemony by coercing them into anomalous and selfhumiliating sexual subjugation and by imposing enforced impregnation. Asked what he observed in female corpses, Major Brent Beardsley who was an assistant to Dallaire gave the following horrifying account: "Yes, two things, really. One, when they killed women it appeared that the blows that had killed them were aimed at sexual organs, either breasts or vagina; they had been deliberately swiped or slashed in those areas. And, secondly, there was a great deal of what we came to believe was rape, where the women's bodies or clothes would be ripped off their bodies, they would be lying back in a back position, their legs spread, especially in the case of very young girls. I'm talking girls as young as six, seven years of age, their vaginas would be split and swollen from obviously multiple gang rape, and then they would have been killed in that position. So they were laying in a position they had been raped; that's the position they were in" (cited in Nowrojee 2007, 364).

4. Road-blocking: roadblocks symbolized the Hutu's determination to obstruct those by whom they were obstructed throughout history. Like a peasant who furiously blocks and kills a porcupine that had destroyed his corn farm, the Hutu Interahamwe and other organized youths blocked the Tutsi and slashed them down remorselessly. The genocidal media advised every Hutu to systematically and methodically hunt down the Tutsi (symbolized as obstructers of the Hutu's identity, prosperity and growth). One perpetrator who was interviewed by RTLM at one of the roadblocks explained how he trapped the Tutsi. He indicated, "When testing if people like a radio station, you ask the following question: who are the speakers of that radio whom you know? Who 
are the RTLM speakers you know? If you do not know them that means that you do not like this radio" (cited in Li 2007, 99).

\section{COSMOLOGICAL METAPHOR}

1. Rivers: rivers are signifiers of flow in the Rwandan cosmology and served during the genocide as organs through which one's hated internal Other was cleaned or eliminated. The use of rivers as metaphor of purification and smooth flow instigated the Hutu to kill the Tutsi and dump them in the rivers. The act was a ritual of purifying 'the Hutuland' from the filth with which they were long contaminated. The slain bodies were thrown in the rivers as a message to send the invaders back to their Nilo-hamitic origin. Taylor (2002) stated that "Rwanda's rivers became part of the genocide by acting as the body politic's organs of elimination, in a sense of excreting its hated internal other. In his rhetoric of exclusion, expunging and extermination made in November 22, 1992, Leon Mugesera tellingly remarked: 'They belong in Ethiopia and we are going to find them a shortcut to get there by throwing them into the Nyabarongo River [which flows northward]. I must insist on this point. We have to act. Wipe them all out!'" (cited in Taylor, 2002, 159). It is believed that soldiers in the Rwandan Patriotic Army (RPA) executed the Hutu persons and threw their bodies in Kager River, the same river where the Hutu extremists threw the bodies of Tutsi victims. The Tutsikilled floating bodies, with hands and feet tied together, were recovered from this river. It is not clear, however, if RPF's similar acts of throwing the dead bodies of Hutu into rivers bears the same cosmological meaning (Moghalu 2005).

2. Excrement: excrement was used to refer to the Tutsi and hence as a dirt that should be removed from the body. The bodies of the Tutsi were thrown in the latrine as excrement.

All of these metaphorical structures emphasized Tutsi's sub-humanity to simplify and justify their annihilation from the land. The killings were made virtuous and every Hutu was called to participate in the ritual purification of the land by removing the obstructing beings that had long blocked the normal flow of the Hutu's identity, integrity and growth (Taylor 2002). The plan worked well and was thus visibly evinced in neighbours' barbarous killings of their own neighbours and in the family members' turn against one another for bloodshed. The genocide, as some may assume, was not the result of an impulsive outburst of aggression that occurred overnight, but the outcome of a politico-militarily orchestrated ideological campaign designed to engender destructive urge in the Hutu mass so that they would get rid of the Tutsi and moderate Hutu. 
The stuff of paranoia and suspicion which the hate media created embedded into the collective consciousness of the majority of the Hutu not only hatred, but also lust and the urge for revenge.

It is implied in the analysis made above that one serious limitation of metaphorical language is its failure to provide a full representation of the reality in the process of transferring thoughts between cognition. Especially when metaphors are used for manipulative purpose or as a propaganda tool, they may hide realities and evoke biases. Oversimplification, overestimations, stereotypical and biased judgements are common in metaphorical systems (Kruglanski et al. 2008). The metaphors usually conceal the other aspects of the domain that are inconsistent with or contradictory to the metaphor. This limitation is ubiquitous in the metaphors that form the basis of genocidal propaganda and wars on terrorism. The Rwandan experience suggests that in divided societies that have history of ethnic and racial hostility, extremists may metaphorically portray the target groups as blood suckers, flesh eaters, filth, and cancerous cell to demonize the group and foment genocidal violence. Such groups unfortunately become scapegoats for predicaments and frustrations experienced both at the political leadership and grassroots levels and are targeted for extermination.

\section{Explaining the Genocide through Violentization Theory}

All of the theories used to explain the genocide in Rwanda commonly suggest that genocidal action is a process of becoming and involves the perpetrators in the process of learning by doing and doing in order to learn. Staub (2002) argues that "mass killing or genocide is usually the outcome of an evolution that starts with discrimination and limited acts of harm-doing. Harming people changes the perpetrators (and the whole society) and prepares them for more harmful acts" (22). The Rwanda genocide and the way the masses participated in it can be understood through various psychological theories of crime causation. One of these theories is the violentization theory which explains genocide as an evolutionary and escalating phenomenon. This theory, developed by Lonnie Athens, identified fundamental stages in the socialization of ordinary human beings into heinous violence. It advances the argument that a full-scale genocide is the extraordinarily worst stage of violence preceded by other stages of violence. The stages are brutalization, belligerency, violent performance, and virulency. This section of the article will attempt to show how each of the stages of violentization was passed prior to and during the genocide.

A). Brutalization: this is the stage at which a person is acclimatized with brutal acts or measures by undergoing brutal experiences, observing the brutalized experiences of others, and teaching or training others on 
how to engage in brutal practices such as torturing and horrifying others. Following the anti-Tutsi campaign that started in response to the RPF's insurgency in 1990, the Hutu had the chance to observe the brutalization of the Tutsi when the latter's massacres were carried out in October 1990, January 1991, February 1991, March 1992, August 1992, January 1993, March 1993 and February 1994. In connection to this, James Waller also adds that the process of brutalization (socialization into brutal acts) "includes a gradual desensitization or habituation to atrocities in which initial, relatively inconsequential, evil actions make later evildoing easier" (2001, 20). According to Duttan et. al. (2004), in the Rwandan context, "desensitization occurred through brutalizing boys who were to be militia by forcing them to kill their own villagers. This practice desensitized the boy, probably traumatized him, and made him an unattached outcast from his own people" (465).

B). Belligerency: this is the stage at which violence becomes a normal and appropriate way of protecting oneself against one's enemy and ensuring one's unthreatened and legitimate existence. In Rwanda, the extremists recalled the populist resistance movement of 1959 and how it enabled the Hutu to gain control over the Tutsi and accordingly reminded people to rise up with similar determination to protect the gains of their revolution. The bloodbath of December 1963 was vaporized as a phenomenal action that broke the backbone of the enemy. It was stressed that such actions are "to protect the Hutu from the permanent threat of feudal bondage" (Kabanda 2007, 68). Prior to and during the genocide, the extremists created a climate for genocide through multiple forms of genocidal priming (Hinton 2002) in order to prepare the Hutu for the mass killing. Phrases that evoke virulency were used in the hate media. Among such expressions was the phrase 'tubatsembasembe' or "let's exterminate them." Weapons were imported and distributed to people for killing. Violent announcements were made that urged the Hutu to act violently. Killing the Tutsi was called self-defence.

C). Violent performance: this stage requires more direct and violent involvement in atrocious killings and brutalization. At this stage, the perpetrators internalize the belief system that violence is right and should be done. Violent behaviours and mad involvement in the genocidal actions are applauded, while failing to overcome psychological inhibitions and revulsions are ridiculed. Those who are expected to be brutal, remorseless, and murderous may be punished and even violently eliminated if they fail to meet the standard of brutality. In Rwanda, both before and during the genocide, innocent Tutsi were horrifically hacked to death with clubs and machetes and their bodies mutilated and thrown in rivers. In addition to gruesome killings, the Rwandan genocide involved sexual violation in the most sadistic and violent manner imaginable. In addition 
to rape, the perpetrators 'sodomized women, raping them with sharp objects and held them in sexual slavery for a number of days and weeks. They used raping as a weapon of domination and subjugation. The perpetrators used penis as weapon of destruction in the same way as they used machetes and tire chains and grenade launchers (Rittner 2009).

D). Virulency: this is the stage at which the individuals and groups involved in violent crimes fully identify themselves as murderously violent. For them, violence is just a way of life and as simple as day-to-day engagement in normal and productive activities. Violence becomes the legitimate means through which they ensure their existence and their ability to put others under their control. Violence becomes the weapon through which the virulent attackers and groups obtain respect and recognition from others. Resistance to violence or an attempt to reverse it is ridiculed and remorselessly punished. In Rwanda, through its fearmongering and hate propaganda, the genocidal media imposed sense of a looming attack on the ordinary Hutu and whipped them into a killing frenzy. In the country, journalism became the powerful weapon of genocide and exhorted the listeners to become virulently violent. It warned them that "the person whose neck you do not cut is the one who will cut yours" (Biju-Duval 2007, 350). Throughout the genocide time, the Tutsi suffered massive dehumanization through violent rape, sexual abuse, and mutilation of body parts that have reproductive and discursive power in the cultural cosmology of the group. Virulency is the most atrocious stage of the violentization process. At this stage, crimes are committed without restraint and people are exceedingly subjected to cruel punishments. They are killed recklessly, tortured terrifyingly, raped indiscriminately and mutilated horrendously. In Rwanda, outrageous killings, brutal rapes, sexual mutilation, raping to death, raping followed by killing and insertion of sharp objects into women's sexual organs were rampant examples of high virulency.

In support of these stages of violentization and on the basis of other empirical works, Staub (2002) reminds us that "People learn and change as a result of their own actions. When they harm other people, a number of consequences are likely to follow. First, they come to devalue the victims more. While in the real world devaluation normally precedes harm-doing, additional devaluation makes greater mistreatment and violence possible" (p. 22). Staub makes another important point that violentization is not only a multi-staged process, but also a self-perpetuating, self-modernizing and self-renewing process. According to him: "As a whole society moves along the continuum of destruction, there is a resocialization in beliefs, values, and standards of conduct. New institutions emerge that serve repression, discrimination, and the mistreatment of identified victims" (2002, p. 24). In the Rwandan case, the govern- 
ment established new media, new styles of communication with the people, and new ideologies to legitimize the annihilation of the vilified group. RTLM, the hate-mongering powerhouse of genocidal incitement, for example, adopted a western radio talk show format and communicated to the people all issues regarding Hutu-Tutsi enmity and conditioned their minds for genocide. The radio broadcasted anti-Hutu songs as entertainment with the aim to indoctrinate the importance of the assault (Fujii 2004).

Instead of always heightening the state of fear and the hugeness of the problem, the Hutu government's hate media sometimes disdained the power of Tutsi and the characteristics of their existence. "The denigration of Tutsi ethnicity was augmented by the visceral scorn coming out of the airwaves the transmitted "the ridiculing laugh and the nasty sneer. These elements greatly amplified the impact of RTLM broadcasts" (Kimani 2007, 112). In general, a violentization process is an aspect of socialization through causing perpetrators to learn brutalization. The process includes among other things gradual desensitization or habituation into atrocities. Persistent engagement in the brutalization process desensitizes the actors' normal and healthy feelings towards acting cruelly even though that action initially becomes abhorrent (Waller 2001, 20). This suggests that the process of violenization involves overcoming internal repulsions that hinder the courage to act violently and shamelessly. It is the process of desensitizing the mind to violence. The desensitization process suggests that a disgusting act of injuring a human being gradually changes into an enjoyable practice. In Rwanda, the process caused rational human beings to rush into barbarism in which killing the perceived enemy was interpreted as virtuous and heroic. Commenting on human savagery and brutality embedded in modern culture and civilisation, Henry Giroux (2012) strongly puts that "brutalizing psychology of desensitization, emotional hardness and the freezing of moral responsibility. . grows out of a formative culture in which war, violence and the dehumanization of others becomes routine, commonplace and removed from any sense of ethical accountability."

In general, the Rwanda genocide shows that the connection between discourses of dehumanization and practical imposition of atrocious brutality was not linear. Rather, the two interacted well since the dehumanization paved the way for physical cruelty. The extremists used the term cockroach so that the Hutu would buy into the image of the Tutsi as despicable and worthy of extinction. This shows how linguistic symbols were selected to dehumanize ethnic groups and validate their annihilation. However, physical mistreatments and violence on its part aggravated devaluation by providing evidence of the crushability, reducibility and eradicablity of the enemy. This interactive relation is true to all sys- 
tems of suppression and the discursive system upon which they are founded.

\section{Concluding Remarks}

The article does not fully answer, but gives reasonable insights into the question of why an ethnic group sets out to eradicate another group from the face of the earth and insight into the interwoven processes involved in the annihilation of a group. One important issue implied in this article is the reproduction of colonial ideology in the Hutu-Tutsi rivalry and the impact of the hamitic myth in this type of rivalry, particularly its role in shaping inter-ethnic 'othering' and marginalization. According to Taylor (2001) the colonial system that shaped the rivalry also "essentializes ethnic difference, justifies political domination by a single group, and nurtures a profound thirst for redress and vengeance on the part of the defavourized group" (2001, 57). The Hutu extremists justified the genocide as a battle between the forces of good and evil. This is the way eliminationists throughout the history of genocide have orchestrated and carried out a group's destruction.

This article has suggested that deployment of discourses of dehumanization plays key role in genocidal violence. This is clear mainly in the symbolized fantasies of violence such as the denigration of the Tutsi as 'cockroaches' with the aim to prime the listeners to crush them. The article has tried to point out the various ways in which discourses of dehumanization shaped the colonial and genocidal history of Rwanda. It has also implied the stages and processes through which the genocidal processes passed. It has also indicated the role linguistic and ethno-cultural symbols played in fuelling ethnic hatred and in enticing the innocent people into active involvement in mass killings. This article has divided discourses of dehumanization into two categories. One obvious form of discursive dehumanization is verbal violence and diminution against an ethnic group. This involves naming and framing an ethnic group through dismissive language such as equating an ethnic group with a hated animal. The metaphorical use of cockroaches to represent the Tutsi is suggestive of the Hutu's supremacist caricature of the Tutsi.

The other discursive mechanism is the direct or practical assault on the basis of ethnic prejudice. In the colonial period, the Belgian colonists imposed discursive dehumanization on the Hutu through their brutal racism that denigrated the Hutu as a sub-human that should be ruled by an allegedly better informed and naturally equipped Tutsi. This caused the Hutu not only to suffer colonially founded and racially guided subjugation, but also to harbour deep bitterness which later came to be melted into vengeful genocide. Even before the 1994 genocide, the Hutu subjected the Tutsi to ranges of assaults. 
The implication of this article for other African states where there is ethnic competition for political and economic positions is that ethnic differences should be resolved peacefully and dialogically instead of falling to calamities that come as a result of polarized differences. The Rwandan experience is a powerful lesson that irremovably polarized ethno-political positions lead to ethnic hostility and exclusion. The genocide could have been prevented had the concerned national and international bodies intervened in the scorching processes of genocidal priming and stimulation. The genocide had profound discursive foundations that finally led to mass slaughter. This article has attempted to stress that genocide is a destructive process that "emerges from a variety of factors, or 'primes,' and that always involves impetus and organization from above, what I call 'genocidal activation" "(Hinton 2002, 36). The article has underlined that among other things the Hutu extremists led the process of 'othering' the Tutsi through rationalizing their eviction and by using dehumanizing rhetoric to demonize them as a threatening and hazardous group.

There is no guarantee that genocide will never come back to Africa if the continent does not develop a constructive process of preventing, managing, and resolving conflicts. One of the things that should be reversed in Africa is the extremist leadership that frames itself on the false propaganda of blocking challenges posed against its rule in the name of protecting its people from snatchers. Instead, a political opportunity must be created for representatives of ethnic groups to discuss issues of common concern to shake together the historical, psychological, and geopolitical causes of their differences. Protecting the fate of one's ethnic group through darkening the fate of other ethnic group cannot be a healthy and civilized choice for political action. However, such a trend seems to persist in Africa unless we go for a political transformation in which leaders assume high responsibility to protect the entire people they govern irrespective of ethnicity, religion, and socio-economic background. The African people's ethnic and political consciousness should also be developed through education. Education fosters a people's rational understanding about the politics of ethnicity and protects them from blindly subscribing to the egoistic interests of their own undemocratic leaders who, like the Hutu-dominated leaders, socialize public compliance for a destructive goal.

\section{REFERENCES}

Afflitto, F.M. (2000). Victimization, survival and the impunity of forced exile: a case study from the Rwandan genocide. Crime, Law \& Social Change 34, 77-97. 
Akhavan, P. (2001). Beyond impunity: can international criminal justice prevent future atrocities? The American Journal of International Law 95, 7-31.

Bhavnani, R. (2006). Ethnic norms and interethnic violence: accounting for mass participation in the Rwandan genocide. Journal of Peace Research 43, 651-669.

Biju-Duval, J. (2007). Hate media- crimes against humanity and genocide: opportunities missed by international criminal tribunal for Rwanda. In The media and the Rwanda genocide, edited by Allan Thomson, 343-361. London: Pluto Press.

Campbell, B. (2010). Contradictory behaviour during genocides. Sociological Forum 25: 296-314.

Charteris-Black, J. (2004). Corpus approaches to critical metaphor analysis. Basingstoke: Palgrave Macmillan.

Des Forges, A. (2007). Call to genocide: radio in Rwanda, 1994. In The media and the Rwanda genocide, edited by Allan. Thomson, 41-54. London: Pluto Press.

Lakoff, G \& Johnson, M. (1980). Metaphors we live by, Chicago: University of Chicago Press.

Dutton, D.G. Boyanowsky, E.O. \& Bond, MH . (2005). Extreme mass homicide: from military massacre to genocide. Aggression and Violent Behaviour 10, 435-473.

Eltringham, N. (2004). Accounting for horror: post-genocide debates in Rwanda. London: Pluto Press.

Fujii, L.A .(2004). Transforming the moral landscape: the diffusion of a genocidal norm in Rwanda. Journal of Genocide Research 6, 99114.

Gellately, R \& Kiernan, B. (2003). The study of mass murder and genocide. In The spectre of genocide: mass murder in historical perspective, edited by Robert Gellately and Ben Kiernan, 3-27. Cambridge: Cambridge University Press.

Glick, P. (2002). Sacrificial lambs dressed in wolves' clothing: envious prejudice, ideology, and the scapegoating of Jews. In Understanding genocide: the social psychology of Holocaust, edited by Leonard S. Newman and Ralph Erber, 113-142. Oxford: Oxford University Press.

Giroux, H. (2012). Violence, USA: The warfare state and the brutalizing of everyday life. Truthout. Accessed June 3, 2012 at http://truthout.org/opinion/item/8859-violence-usa-the-warfare-state-and-thebrutalizing-of-everyday-life. 
Hackett, R.J. (2003). Discourses of dehumanization in Africa and beyond. Diogenes 50, 61-75.

Hagan, J \& Rymond-Richmond, W. 2008. The collective dynamics of racial dehumanization and genocidal victimization in Darfur. American Sociological Review 73, 875-902.

Higiro, J.V. (2007). Rwandan private print media on the eve of the genocide. In The media and the Rwanda genocide, edited by Allan Thomson, 73-89. London: Pluto Press.

Hinton, A.L. (2002). The dark side of modernity: Toward anthropology of genocide. In Annihilating difference: the anthropology of genocide, edited by Alexander L. Hinton, 1-40. Berkley: University of California Press.

Jones, A. (2002). Gender and genocide in Rwanda. Journal of Genocide Research 4, 65-94.

Kabanda, M. (2007). Kangura: The triumph of propaganda refined. In The media and the Rwanda genocide, edited by Allan Thomson, 6272. London: Pluto Press.

Kamola, I.A. (2007). The global coffee economy and the production of genocide in Rwanda. Third World Quarterly 28, 571-592.

Kaufman, S.I. (2006). Symbolic politics or rational choice/ testing theories of extreme ethnic violence. International Security 30, 45-86.

Kimani, M. (2007). RTLM: the medium that became a tool for mass murder. In The media and the Rwanda genocide, edited by Allan Thomson, 110-124. London: Pluto Press.

Kruglanski, A.W., Crenshaw, M, Post, JM \& Victoroff, J. (2008). What should this fight be called? Metaphors of counterterrorism and their implications. Psychological Science in the Public Interest 8, 97-133.

Lederach, P. (1997). Building peace: sustainable reconciliation in divided societies. Washington, D.C. United states Institute of Peace Press.

Li, D. (2007). RTLM: the medium that became a tool for mass murder. In The media and the Rwanda genocide, edited by Allan Thomson, 90-109. London: Pluto Press.

Linke, U. (2002). Archives of violence: The holocaust and the German politics of memory. In Annihilating difference: the anthropology of genocide, edited by Alexander L. Hinton, 229-271. Berkley: University of California Press. 
Mironko, C. (2007). The effect of RTLM's rhetoric of ethnic hatred in rural Rwanda. In The media and the Rwanda genocide, edited by Allan Thomson, 110-124. London: Pluto Press.

Moghalu, K.C. (2005). Rwanda's genocide: the politics of global justice. New York: Palgrave.

Nowrojee, B. (2007). A lost opportunity for justice: why did the ICTR not prosecute gender propaganda. In The media and the Rwanda genocide, edited by Allan Thomson, 362-372. London: Pluto Press.

Reyntjens, F. (1987). Chiefs and burgomasterns in Rwanda: the unfinished quest for a bureaucracy. Journal of Legal Pluralism 25, 71-97.

Rittner, C. (2009). Rape, religion, and genocide: an unholy silence. In Confronting genocide: Judaism, Christianity, Islam, edited by Steven L. Jacobs, 291-306. Lanham: Lexington Books.

Schimmel, N. (2011). An invisible genocide: how the western media failed to report the 1994 rwandan genocide of the Tutsi and why. The International Journal of Human Rights, 15, 1125-1135.

Stanton, G.H. (2004). Could the Rwandan genocide have been prevented? Journal of Genocide Research 6, 211-228.

Staub, E. (2002). The psychology of bystanders, perpetrators and heroic helpers. Understanding genocide: the social psychology of the Holocaust, edited by L. S. Newman \& R. Erber, 11-42. Oxford: Oxford University Press.

Staub, E., Pearlman, LA., Gubin, A., Hagengimana, A. (2005). Healing, reconciliation, forgiving and the prevention of violence after genocide or mass killings: an intervention and its experimental evaluation in Rwanda. Journal of Social and Clinical Psychology 24, 297334.

Straus, S. (2004). How many perpetrators were there in the Rwandan genocide? An estimate. Journal of Genocide Research 6, 85-98.

Taylor, C.C. (2001). Sacrifice as terror: The Rwandan genocide of 1994. Oxford: Berg Publishers.

Taylor, C.C. (2002). The cultural face of terror in the Rwandan genocide. In A.L. Hinton (Ed.). Annihilating difference: the anthropology of genocide (p. 137-178). Berkley: University of California Press.

Waller, J. (2001). Perpetrators of genocide: an explanatory model of extraordinary human evil. Journal of Hate Studies 1, 5-22.

White, K.R. (2009). Scourge of racism: genocide in Rwanda. Journal of Black Studies 39, 471-481. 
Winton, M.A. (2008). Dimensions of genocide: the circumflex model meets violentization theory. The Qualitative Report 13, 605-629.

Winton, M.A. (2011). Violentization theory and genocide. Homicide Studies 15, 363-381.

Winton, M.A., \& Unlu, A. (2007). Micro-macro dimensions of the Bosnian genocides: the circumplex model and violentization theory. $\mathrm{Ag}$ gression and Violent Behavior, 13, 45-59.

Woolf, L. M. \& Hulsizer, M. R. (2005). Psychosocial roots of genocide: risk, prevention, and intervention. Journal of Genocide Research 7, 101-128. 